\title{
UPAYA MENGOPTIMALKAN KEBERSIHAN RUANG MUAT SEBELUM PROSES PEMUATAN
}

\author{
Vega F. Andromeda ${ }^{a}$ dan Fathnurrokhim A.F. Ramadhan ${ }^{b}$ \\ ${ }^{a}$ Dosen Program Studi Nautika PIP Semarang \\ ${ }^{\mathrm{b}}$ Taruna (NIT.49124414.N) Program Studi Nautika PIP Semarang
}

\begin{abstract}
ABSTRAK
Ruang muatan yang disiapkan dengan baik merupakan faktor yang sangat penting dalam pelaksanaan kegiatan bongkar muat, sehingga kegiatan bongkar muat dapat berjalan dengan efektif dan efisien. Berdasarkan hasil penelitian, proses bongkar muat pada saat kapal akan berlabuh di pelabuhan Antwerpen Belgia terhambat dikarenakan waktu pembersihan ruang muat tidak mencukupi serta peralatan perlengkapan kebersihan ruang muat banyak yang rusak dan tidak layak pakai sehingga ruang muat masih kotor dan belum siap untuk menerima muatan. Tujuan dari penelitian ini yaitu untuk mengetahui penyebab kurangnya waktu pembersihan dan penyebab rusaknya peralatan kebersihan ruang muat.

Proses pembersihan ruang muat yang tidak sesuai dengan prosedur terjadi karena kurangnya pengawasan, koordinasi, komunikasi dan perawatan peralatan kebersihan ruang muat. Upaya untuk mengatasi agar proses pembersihan ruang muat tepat waktu yaitu meningkatkan koordinasi antarawak kapal dan melakukan perawatan terhadap alat-alat kebersihan ruang muat. Pembersihan ruang muat dapat berjalan lancar apabila dilaksanakan sesuai dengan prosedur yang ada dan peralatan kebersihan yang memenuhi standart.
\end{abstract}

\section{Kata kunci: persiapan, ruang muat, proses bongkar muat, optimalisasi}

\section{PENDAHULUAN}

Di dalam suatu negara maritim seperti halnya negara Indonesia, peranan pelayaran sungguh sangat penting bagi kehidupan sosial ekonomi.

Kapal-kapal niaga yang beroperasi di dunia untuk melakukan pengangkutan barang-barang, sungguh sangat banyak jenisnya. Hal ini tidak mengherankan, karena jenis-jenis barang niaga yang harus diangkut oleh kapal tiada terbatas. Adanya barang-barang yang harus diangkut dalam keadaan tertentu, pelabuhan-pelabuhan muatan dan pelabuhan tujuan muatan yang berbeda-beda, barang-barang tertentu yang berpotensi saling merusakan jika dicampur, menimbulkan jenis-jenis kapal yang berbeda-beda, disamping itu sifat-sifat perairan yang berbeda-beda (perairan tropic, musim dingin, perairan sungai dan danau) juga ikut menentukan jenis-jenis kapal niaga yang harus dibangun. Demikianlah dalam dunia pelayaran niaga modern, kita telah mengenal adanya kapal general cargo carrier.

General Cargo carrier adalah kapal yang dibangun untuk tujuan mengangkut muatan umum (general cargo), yaitu muatan yang terdiri dari bermacam-macam barang yang dibungkus dalam peti, keranjang, dan lainlain, dan barang-barang itu dimuat dalam kapal oleh banyak pengirim untuk ditujukan kepada banyak penerima di banyak pelabuhan tujuan.

Kapal general cargo carrier dibangun dengan beberapa palka (hold hatches) dan beberapa geladak. Palka-palka dan geladakgeladak yang banyak jumlahnya memang sangat perlu bagi sebuah kapal general cargo, sebab seperti telah dikatakan di muka barang-barang dalam partai-partai kecil dikirim oleh banyak pengirim dari banyak pelabuhan untuk ditujukan kepada banyak penerimaan di banyak pelabuhan tujuan, dengan adanya banyak geladak pembagian muatan di dalam ruang kapal (compartment) dapat diatur dengan mudah 
dan tidak menimbulkan kesulitan dalam pembongkarannya di pelabuhan tujuan barang masing-masing, juga untuk mencegah kerusakan muatan karena kontaminasi oleh sesama muatan.

Dengan banyaknya palka atau ruang muat pada kapal maka untuk membersihkan ruang muat tersebut membutuhkan waktu yang tidak sebentar ditambah lagi peralatan kebersihan ruang muat harus dalam keadaan layak pakai.

Berdasarkan dari latar belakang penelitian di atas, maka peneliti dapat mengambil rumusan masalah sebagai berikut :

1. Mengapa waktu yang tersedia belum mencukupi dalam persiapan ruang muat di kapal MV. African Forest ?

2. Apa yang menyebabkan perlengkapan pembersihan atau pencucian ruang muat tidak mencukupi serta banyak dari peralatan tersebut yang rusak ?

Dalam penelitian ini terdapat beberapa tujuan yang hendak dicapai oleh peneliti, yaitu sebagai berikut :

1. Untuk mengetahui mengapa waktu yang tersedia belum mencukupi dalam persiapan ruang muat di kapal MV. African Forest.

2. Untuk mengetahui masalah apa yang menyebabkan perlengkapan pembersihan atau pencucian palka tidak mencukupi serta banyak dari peralatan tersebut yang rusak.

Adapun maksud dan tujuan dari pada penelitian ini diharapkan mampu memberikan masukan atau manfaat dari penelitian bagi pihak-pihak yang terkait dengan dunia pelayaran, dunia keilmuan, institusi pelayaran dan pengetahuan serta bagi individu, seperti:

a) Manfaat Secara Teoritis

1) Untuk menambah pengetahuan bagi pembaca, pelaut, maupun kalangan umum agar dapat menangani masalah, saat terjadi keterlambatan dalam bongkar muat di pelabuhan.

2) Untuk menambah pengetahuan bagi pembaca, pelaut, maupun kalangan umum dalam memahami tentang pentingnya kebersihan ruang muat sebelum memulai proses pemuatan.

3) Menambah pengetahuan bagi Taruna tentang pentingnya penanganan keterlambatan dalam proses bongkar muat.

b) Manfaat Secara Praktis

1) Diharapkan dapat menjadi masukan gambaran dan penjelasan bagi pembaca khususnya perwira yang sedang dan akan bekerja di kapal general cargo agar lebih memahami dan mengetahui prosedur pembersihan ruang muat sebelum melakukan proses pemuatan.

2) Diharapkan dapat menjadi bahan pembelajaran bagi awak kapal pada kapal general cargo mengenai pentingnya menjaga dan merawat alat-alat kebersihan ruang muat di atas kapal.

\section{KAJIAN PUSTAKA}

\section{A. Persiapan Ruang Muat}

Menurut Capt. Istopo dan Capt. O. S. Karlio (2002: 235-236), untuk mempersiapan ruang muat perlu dilakukan beberapa hal antara lain yaitu:

1. Menyapu bersih mulai dari atas ke bawah. Jadi tween deck terlebih dahulu baru menyusul lower hold. Bekas papanpapan dunnage atau penyangga muatan terdahulu, dikumpulkan jadi satu diikat di tempat yang sudah bersih. Yang rusak atau dapat merusak muatan seperti yang berminyak harus disingkirkan dari dalam palka.

2. Membuka tutup-tutup got, dan harus diperiksa oleh seorang Mualim. Saringan kemarau atau 'strumboxes' dibersihkan dan dites pompa lensanya, dengan menggunakan kaleng berisi air, scupper di tween deck juga harus dites, sumbatan-sumbatan dilepas apabila muatan sebelumnnya adalah bulk cargo, 
setelah itu papan-papan penutup got dan strumboxes dipasang kembali.

3. Alat-alat kebakaran atau alat $\mathrm{CO}_{2}$ harus dites.

4. Papan-papan penutup palka di tween deck harus diperiksa kondisinya.

5. Papan-papan penutup tanki dasar berganda diperiksa dan ditempatkan yang baik.

6. Pagar-pagar keamanan (guard rail), rantai atau tiangnya yang berada di tween deck dipasang semestinya. Dalam hal ini perlu diperingatkan terutama pada kapal-kapal yang berlayar ke Eropa dan Australia, dimana keamanan buruh sangat diperhatikan.

\section{B. Bulk Cargo}

Menurut Sudjatmiko (2011:67), bulk cargo (muatan) curah adalah muatan yang terdiri dari suatu muatan yang tidak dikemas yang diangkut oleh kapal sekaligus dalam jumlah yang besar. Muatan curah kering merupakan muatan padat dalam bentuk bijibijian, bubuk, butiran, dan sebagainya yang dalam pemuatan atau pembongkaran dilakukan dengan mencurahkan muatan kedalam ruang muat dengan menggunakan alat khusus. Contoh muatan curah adalah biji gandum, kedelai, jagung, pasir, semen, klinker, soda, maize gritze, malt, dan lain sebagainya. Persiapan ruang muat bagi kapal-kapal general cargo:

1. Palka dan tween deck disapu bersih seluruhnya dari atas ke bawah.

2. Papan-papan penutup dasar berganda (spare ceiling) ditutup rapat grain tight agar biji-bijian tidak masuk ke dalam got.

3. Semua dunnage disingkirkan dari ruangan palka atau disimpan diujung palka dan ditutup. Got-gotnya disapu dan dibersihkan, dan pompa lensanya dicoba.

4. Alat-alat kebakaran dites.

\section{METODOLOGI}

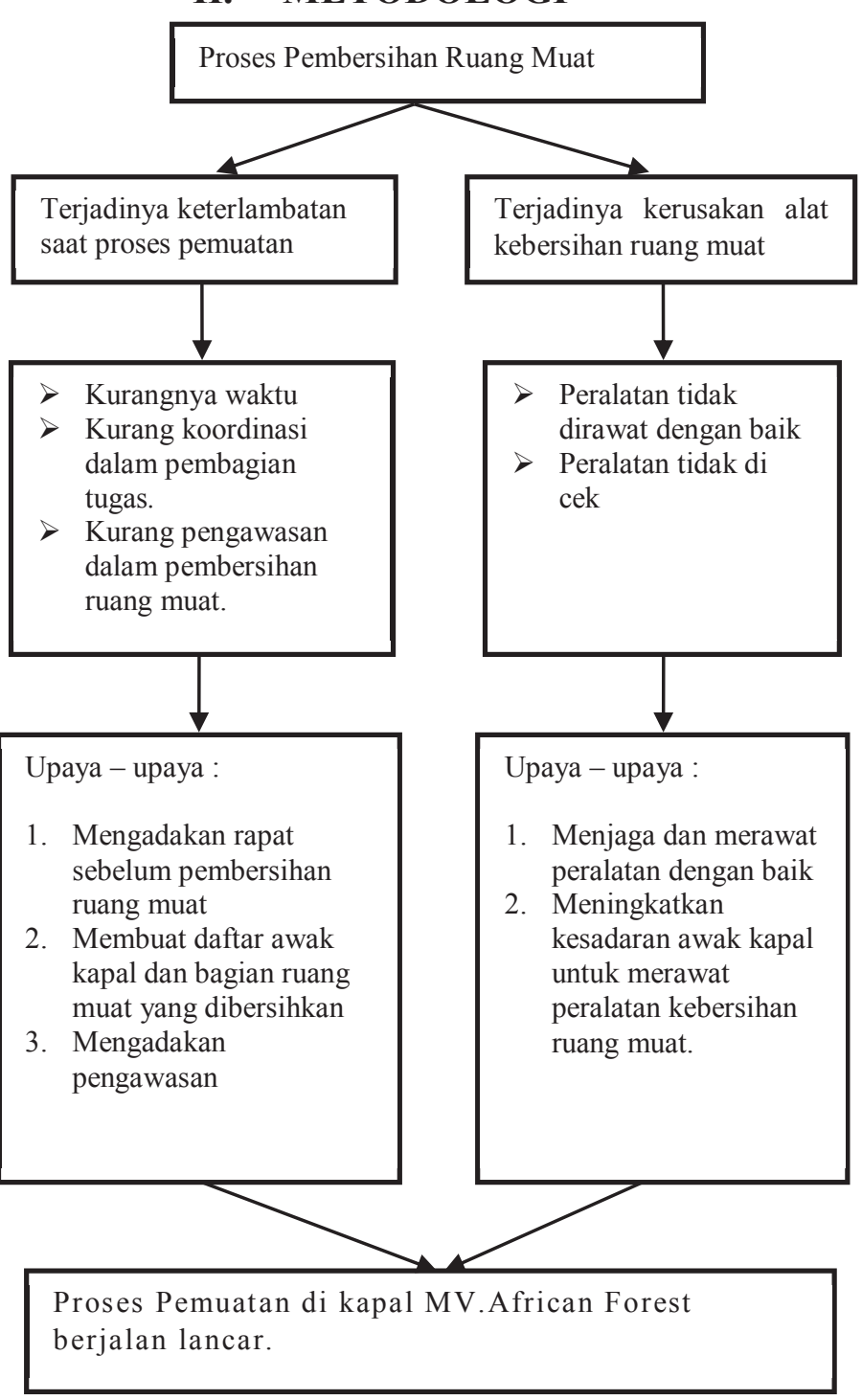

Gambar 1. Kerangka Pikir Penelitian

Berdasarkan bagan kerangka berfikir di atas dapat diketahui penyebab dan penanganan keterlambatan proses pemuatan di kapal MV. African Forest, adapun penjabaran dari kerangka berfikir diatas ialah sebagai berikut :

a. Kapal MV. African Forest adalah kapal jenis General Dry Cargo Heavylift Multipurpose dengan sistem Fully Loaded yang memuat berbagai macam muatan dalam proses bongkar muat. Dalam pemuatan cargo kapal MV. African Forest selalu melaksanakan proses pemuatan di Benua Eropa. Dalam proses pemuatan sering 
terjadi hambatan, masalah kebersihan ruang muat yang mengakibatkan terlambatnya proses pemuatan. Dalam permasalahan ini akan dibahas tentang penyebab terjadinya keterlambatan proses pemuatan di kapal MV. African Forest dan penanganannya.

b. Terjadinya kerusakan pada alat-alat kebersihan ruang muat sehingga alat-alat kebersihan ruang muat tidak layak pakai karena kurangnya kesadaran awak kapal untuk menjaga dan merawat alat kebersihan setelah selesai menggunakannya, sehingga ruang muat tidak bisa bersih secara maksimal dan masih terdapat kotoran sisa muatan sebelumnya di dalam ruang muat.

c. Dari permasalahan keterlambatan proses pemuatan maka dapat diambil tindakan penanganan meliputi pelaksanakan pemuatan sesuai prosedur, melaksanakan rapat sebelum memulai kegiatan pembersihan ruang muat, melaksanakan tanggung jawab dengan sebaik mungkin, melakukan perawatan dan pengecekan terhadap peralatan kebersihan kapal, mengadakan pengawasan, selalu berkomunikasi kepada semua kru (perwira dan anak buah kapal) untuk kelancaran dalam proses pemuatan.

d. Sasaran dari seluruh tindakan yang telah dilakukan yaitu pelaksanaan pemuatan yang tepat waktu dan lancar sesuai dengan prosedur yang telah dibuat.

\section{A. Metode Penelitian}

Metode penelitian yang digunakan oleh peneliti di dalam menyampaikan masalah adalah USG (Urgency, Seriousness, Growth) untuk menggambarkan dan menguraikan prioritas masalah dalam objek yang diteliti. Berdasarkan jenis penelitian tersebut, maka penelitian ini akan menghasilkan prioritas-prioritas masalah dalam suatu proses pelaksanaan kebersihan ruang muat.

Dalam pelaksanaan kegiatan tidak terlepas dari pentingnya sebuah perencanaan. Salah satu aspek perencanaan sebagai langkah awal adalah dengan menentukan prioritas masalah (problem priority). Penetapan prioritas masalah menjadi bagian penting dalam proses perumusan masalah. Penentuan prioritas masalah ada beberapa metode yang dapat digunakan yaitu dalam istilah Urgency, Seriousness and Growth yang artinya adalah:

1. Urgency adalah tingkat kegawatan masalah, berkaitan dengan mendesaknya waktu yang diperlukan untuk menyelesaikan masalah tersebut. Seberapa mendesak isu tersebut harus dibahas dikaitkan dengan waktu yang tersedia serta seberapa keras tekanan waktu untuk memecahkan masalah yang menyebabkan isu tersebut.

2. Seriousness adalah tingkat keseriusan sebuah masalah, berkaitan dengan dampak dari adanya masalah tersebut terhadap organisasi. Seberapa serius isu tersebut perlu dibahas dikaitkan dengan akibat yang timbul dengan penundaan pemecahan masalah yang menimbulkan isu tersebut atau akibat yang menimbulkan masalah-masalah lain jika masalah penyebab isu tidak dipecahkan. Perlu dimengerti bahwa dalam keadaan yang sama, suatu masalah yang dapat menimbulkan masalah lain lebih serius bila dibandingkan dengan suatu masalah lain yang berdiri sendiri.

3. Growth adalah berkaitan dengan pertumbuhan masalah. Semakin cepat berkembang masalah tersebut maka semakin tinggi tingkat pertumbuhannya. Seberapa mungkin isu tersebut menjadi berkembang dikaitkan kemungkinan masalah penyebab isu akan semakin buruk bila diabaikan.

Metode USG merupakan salah satu cara menetapkan urutan prioritas masalah dengan metode teknik scoring. Caranya dengan menentukan Urgency, Seriousness, dan Growth dengan menggunakan skala nilai 15 , suatu masalah dengan total skor tertinggi merupakan masalah yang prioritas. Adapun keterangan skor sebagai berikut: 
Tabel 1. Skala Penilaian Metode USG

\begin{tabular}{|c|c|}
\hline Skala & Penilaian \\
\hline 1 & Sangat kecil \\
\hline 2 & Kecil \\
\hline 3 & Sedang \\
\hline 4 & Besar \\
\hline 5 & Sangat besar \\
\hline
\end{tabular}

\section{B. Data yang Diperlukan}

Untuk menyusun penelitian ini peneliti memerlukan sumber data. Yang dimaksud dengan sumber data adalah dari mana data diperoleh atau semua informasi baik dari yang merupakan benda nyata, sesuatu yang abstrak, maupun peristiwa yang terjadi pada waktu peneliti melaksanakan penelitian. Menurut Riduwan (2003:31), Data ialah bahan mentah yang perlu diolah sehingga menghasilkan informasi atau keterangan yang menunjukkan fakta. Menurut Sugiyono (2013:223), Pengumpulan data dapat dilakukan dalam berbagai setting, berbagai sumber dan berbagai cara. Bila dilihat dari sumber datanya, maka pengumpulan data dapat menggunakan sumber primer dan sumber sekunder. Data yang diperoleh selama penelitian sebagai pendukung tersusunnya penulisan penelitian ini adalah sebagai berikut:

1. Data Primer Pengertian data primer menurut Umi Narimawati,SE.,M.Si (2008:98) adalah data yang berasal dari sumber asli atau pertama. Data ini tidak tersedia dalam bentuk terkompilasi ataupun dalam bentuk file-file. Data ini harus dicari melalui narasumber atau dalam istilah teknisnya responden, yaitu orang yang kita jadikan objek penelitian atau orang yang kita jadikan sebagai sarana mendapatkan informasi ataupun data.

2. Data Sekunder Menurut Sugiyono (2008:402) data sekunder adalah sumber data yang tidak langsung memberikan data kepada pengumpul data. Data sekunder ini merupakan data yang sifatnya mendukung keperluan data primer seperti buku-buku, literatur dan bacaan yang berkaitan dengan masalah yang dibahas di dalam penelitian ini.

Untuk memperoleh gambaran secara lengkap, utuh dan menyeluruh maka disamping adanya data primer masih diperlukan adanya data tambahan yang dinamakan data sekunder. Jadi, data sekunder ini bersifat mendukung dan melengkapi data primer. Adapun yang termasuk data sekunder adalah data yang diperoleh dengan kata lain secara tidak langsung. Data sekunder yang diperoleh peneliti melalui buku-buku publikasi navigasi, buku-buku manual atau mungkin hasil survei yang belum diolah dan dianalisa lebih lanjut yang dapat menghasilkan sesuatu yang berguna. Dan juga diperoleh melalui buku-buku yang berkaitan, misal dalam perpustakaan, hasil seminar, dan arsip peraturan penelitian baik nasional maupun internasional yang menunjang penelitian.

\section{Pengumpulan Data}

Metode pengumpulan data ialah teknik atau cara-cara yang dapat digunakan oleh peneliti untuk mengumpulkan data. Selain teknik pengumpulan data yang harus tepat, alat pengumpulan data juga harus baik. Dengan demikian, data yang dikumpulkan bersifat baik dan benar.

Dalam melakukan pengumpulan data tentu peneliti membutuhkan banyak sumber untuk dituangkan sebagai pokok bahasan di dalam penelitian ini. Karena itu lebih baik menggunakan suatu pengumpulan data lebih dari satu, sehingga semua dapat saling melengkapi satu sama lain untuk pembuatan penelitian ini dengan baik. Pengumpulan data merupakan langkah penting dalam suatu penelitian yang akan digunakan sebagai bahan analisis dan pengujian kesimpulan. Oleh karena itu, pemilihan teknik data dan pengumpulan data yang tepat dapat membantu pencapaian hasil atau pemecahan masalah yang tepat dan benar. Di dalam penelitian ini peneliti menggunakan beberapa teknik pengumpulan data antara lain:

1. Riset lapangan 
Teknik pengumpulan data dengan melakukan pengamatan secara langsung ke objek penelitian. Riset ini dilakukan dengan 3 cara, yaitu:

a. Metode observasi yaitu suatu proses yang kompleks, suatu proses yang tersusun dari berbagai proses biologis dan psikologis.

b. Metode wawancara yaitu pertemuan dua orang untuk bertukar informasi dan ide melalui tanya jawab, sehingga dapat dikonstruksikan makna dalam suatu topik tertentu.

c. Metode dokumentasi yaitu catatan peristiwa yang sudah berlalu.

\section{Riset kepustakaan}

Teknik ini berkaitan dengan kajian teoritis dan referensi lain yang berkaitan dengan nilai, budaya dan norma yang berkembang pada situasi sosial yang diteliti. Studi kepustakaan penting untuk penelitian karena penelitian tidak akan lepas dari literatur-literatur ilmiah.

\section{Prosedur Penelitian}

Rancangan penelitian dalam penulisan penelitian ini memudahkan peneliti dalam hal-hal yang berhubungan dengan penelitian. Rancangan penelitian ini meliputi pengumpulan data, membahas data dan disimpulkan yang kemudian dituangkan dalam penelitian ini. Pada bagian ini mempersoalkan tahap-tahap penelitian yang nantinya memberikan gambaran tentang keseluruhan perencanaan, pelaksanaan pengumpulan data, analisis data, sampai pada penulisan laporan.

\section{DISKUSI}

\section{A. Gambaran Umum Obyek Yang Diteliti}

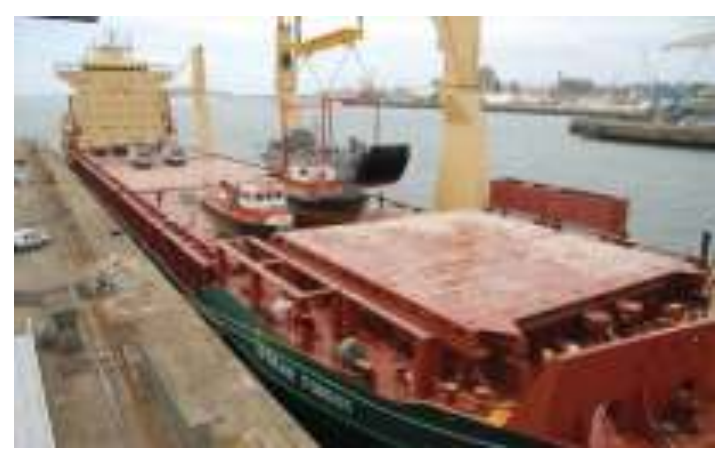

Gambar 2. MV. African Forest

MV. African Forest adalah salah satu unit kapal berbendera Antigua and Barbuda milik Lubeca Marine Germany, dengan trayek pelayaran charter oleh B.O.C.S (Bremen Overseas Chartering and Shipping) dari Rord Braren Bereederungs GmbH \& Co.KG, Germany yang memiliki trayek pelayaran dari Benua Eropa menuju ke Benua Afrika dan begitupun sebaliknya dari Benua Afrika menuju ke Benua Eropa. Kapal MV. African Forest merupakan kapal General Cargo Heavylift Multipurpose kelas Germanischer Lloyd Register dan jenis muatan yang dimuati adalah berbagai macam muatan curah ataupun dalam peti kemas. Dengan data-data kapal (Ship's Particular) sebagai berikut:

\begin{tabular}{|c|c|}
\hline 1. SHIP NAME & : MV. AFRICAN FOREST \\
\hline 2. CALL SIGN & : V2FF4 \\
\hline 3. MMSI & : 305659000 \\
\hline 4. TYPE & : GENERAL CARGO \\
\hline 5. PORT OF REGISTER & : St. JOHNS \\
\hline 6. FLAGE STATE & : ANTIGUA \& BARBUDA \\
\hline $\begin{array}{l}\text { 7. CLASSIFICATION } \\
\text { LLOYD }\end{array}$ & GERMANISCHER \\
\hline 8. IMO NUMBER & : 9425162 \\
\hline 9. GRT & : 20973MT \\
\hline 10. NRT & : 10262MT \\
\hline 11. YEAR OF BUILD & : 2011 \\
\hline 12. L O A & : 166.44 MTRS \\
\hline 13. L B P & : 159.33MTRS \\
\hline 14. DEPTH MOULDED & $: 14.20 \mathrm{MTRS}$ \\
\hline 15. DATE OF KEEL LAID & : 15.12 .2008 \\
\hline 16. BREADTH & : 27.40 MTRS \\
\hline 17. LIGHT SHIP & $9670.46 \mathrm{MT}$ \\
\hline MAIN ENGINE TYPE & : MAN B \& W : 6S40ME-B9 \\
\hline
\end{tabular}

\section{B. Analisa Masalah}

Analisa masalah yang akan peneliti gunakan yaitu metode USG (Urgency, Seriousness, Growth) untuk mengetahui hasil dari penyebab keterlambatan proses pemuatan di kapal MV. African Forest. Selanjutnya akan dilakukan upaya untuk memecahkan masalah-masalah yang ada, dengan melakukan peninjauan dan melakukan perbandingan dengan teori yang ada, serta prosedur yang tepat untuk digunakan dalam proses pembersihan ruang muat. Peneliti menemukan empat masalah yang kemudian dengan menggunakan matriks USG peneliti mencoba mendapatkan 
prioritas utama yang harus segera diselesaikan denga baik untuk meningkatkan kebersihan ruang muat sebelum proses pemuatan di kapal MV. African Forest. Adapun hasil dari matrik USG tersebut peneliti tampilkan pada tabel berikut:

Tabel 2. Matriks USG

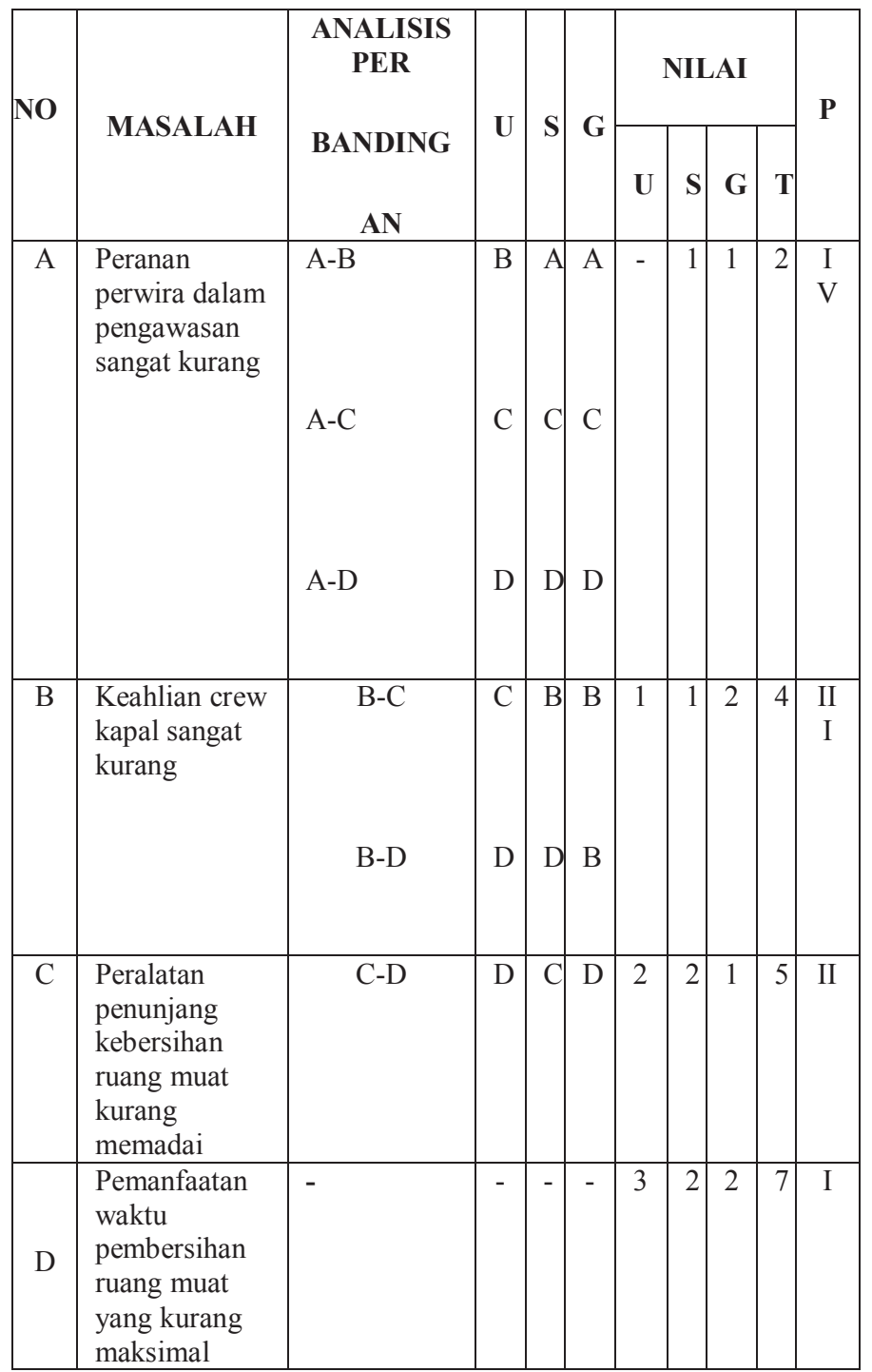

\section{Terjadi keterlambatan dalam proses pemuatan}

Adanya beberapa hal yang sering menyebabkan terjadi keterlambatan dalam proses bongkar muat :

\section{a. Kurangnya waktu yang tersedia untuk melaksanakan waktu pembersihan ruang muat}

Proses pembersihan ruang muat diatas kapal melibatkan seluruh awak kapal. Pihak kapal yang berwenang adalah Mualim I sebagai penanggung jawab dalam kebersihan ruang muat di bawah wewenang Nakhoda selanjutnya Bosun yang bertanggung jawab atas semua awak kapal yang melakukan proses pembersihan ruang muat. Dan proses pembersihan ruang muat tidak sesuai dengan prosedur yang ada. Dikarenakan kapal MV. African Forest mempunyai banyak ruang muat dan seluruh ruang muat tersebut harus bersih untuk menerima muatan selanjutnya sedangkan waktu yang tersedia sangat pas bahkan kurang untuk menyelesaikan proses pembersihan semua ruang muat yang ada di kapal, karena apabila masih ditemukan sisa kotoran dari muatan sebelumnya maka dari pihak Cargo surveyor tidak akan memberi izin kepada pihak kapal untuk melakukan proses pemuatan.

\section{b. Kurang koordinasi dalam pembagian tugas}

Salah satu penyebab terlambatnya proses pemuatan karena ruang muat kotor adalah kurangnya koordinasi dalam pembagian tugas, sehingga awak kapal tidak mempunyai target dan tujuan ruang muat yang manakah yang harus diselesaikan terlebih dahulu dalam proses pembersihan ruang muat, sehingga para awak kapal bekerja dalam proses pembersihan ruang muat dengan kacau dan tidak terkoordinasi dengan baik. Sehingga dengan adanya kejadian tersebut, proses pemuatan dalam ruang muat pada kapal mengalami keterlambatan beberapa jam. Kejadian ini pernah dialami oleh kapal MV. African Forest saat kapal berada di Rouen, France. Pada saat kapal telah sandar di pelabuhan cargo surveyor datang dan naik ke atas kapal kemudian cargo surveyor memeriksa keadaan ruang muat yang akan di gunakan untuk memuat muatan maize gritz dan cargo surveyor menemukan ruang muat 
masih kotor dan belum layak untuk menerima muatan, sehingga para awak kapal harus melakukan kegiatan pembersihan ruang muat ulang agar ruang muat benar-benar siap untuk menerima muatan.

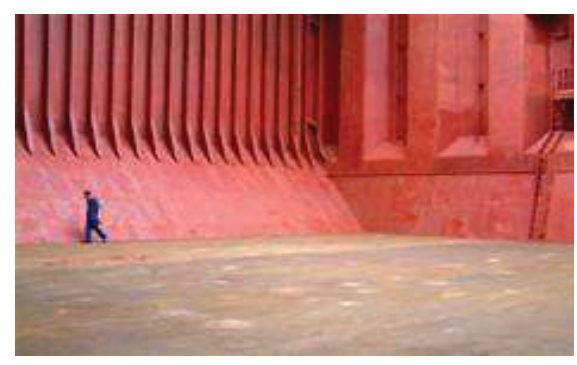

Gambar 3. Cargo surveyor memeriksa ruang muat

\section{c. Kurang pengawasan dalam pembersihan ruang muat}

Dalam proses pembersihan ruang muat, Mualim I selaku perwira yang bertanggung jawab terhadap proses pembersihan ruang muat di bawah Nakhoda masih sangat kurang karena tidak ada pengecekan yang dilakukan oleh Mualim I dan tidak ada juga bimbingan serta arahan atau instruksi yang diberikan oleh Mualim I kepada bosun atau awak kapal dalam proses pembersihan ruang muat, sehingga awak kapal dengan semena-mena dalam bekerja membersihkan ruang muat, para awak kapal melakukan kebersihan ruang muat tidak sesuai dengan prosedur dan tidak maksimal dalam melakukan pembersihan ruang muat. Pernah peneliti alami di atas kapal, saat melakukan pembersihan ruang muat. Para awak kapal yang melakukan pembersihan ruang muat hanya membersihkan ruang muat dengan cara dibilas dengan menggunakan air laut yang disalurkan melalui hoze dari fire hydrant dengan tanpa menggunakan chemical soap dan tanpa melakukan proses brush dengan menggunakan alat-alat penunjang kebersihan ruang muat, setelah selesai melakukan proses pembilasan terhadap dinding dan lantai pada ruang muat para awak kapal pun tidak melakukan proses pengeringan terhadap ruang muat. Akibatnya ruang muat tidak bersih maksimal dan masih terdapat sisa-sisa kotoran dari muatan sebelumnya di dalam ruang muat. Sehingga pada saat Cargo surveyor melakukan pengecekan terhadap ruang muat, Cargo surveyor menyatakan bahwa ruang muat belum siap untuk menerima muatan dan Cargo surveyor tidak akan menandatangani proses memuat muatan selama masih ditemukan sisa-sisa kotoran yang masih terdapat di dalam ruang muat.

\section{Terjadinya kerusakan alat kebersihan ruang muat}

Adanya beberapa hal yang sering menyebabkan terjadinya keterlambatan pemuatan di kapal MV. African Forest yang dikarenakan oleh terjadinya kerusakan pada alat-alat penunjang kebersihan ruang muat, diantaranya:

a. Peralatan tidak dirawat dengan baik

Dalam melakukan proses pembersihan ruang muat para awak kapal menggunakan alat-alat penunjang kebersihan ruang muat seperti : sapu, sikat, pel, rugs, dan masih banyak lagi alat-alat penunjang kebersihan ruang muat yang lainnyya yang digunakan oleh awak kapal dalam proses pembersihan ruang muat. Setelah selesai mengunakan alat-alat penunjang kebersihan ruang muat tersebut para awak kapal hanya meletakkan peralatan tersebut begitu saja tanpa diposisikan dan di tata supaya rapi dan tidak rusak, kurangnya kesadaran awak kapal untuk menjaga dan merawat peralatan kebersihan ruang muat tersebut menyebabkan peralatan kebersihan ruang muat rusak dan tidak layak lagi digunakan dalam proses pembersihan ruang muat, sehingga mengakibatkan 
proses pembersihan ruang muat membutuhkan waktu yang sangat lama karena peralatan yang sudah rusak dan tidak layak lagi untuk digunakan.

\section{b. Peralatan tidak di cek}

Peralatan penunjang kebersihan ruang muat yang selanjutnya adalah pompa yang terdapat pada got di dalam ruang muat yang berfungsi untuk memompa air keluar dari dalam ruang muat setelah ruang muat selesai dibilas dengan menggunakan air. Karena letaknya yang sulit untuk dijangkau maka pompa tersebut sering diabaikan oleh para awak kapal untuk dilakukan pengecekan, seharusnya sebelum melakukan proses pembilasan ruang muat pompa tersebut dicek terlebih dahulu sehingga dapat bekerja secara maksimal dalam memompa air keluar dari ruang muat. Pernah peneliti alami di atas kapal pada saat ruang muat selesai dibilas pompa tersebut macet dan tidak bisa digunakan untuk memompa air keluar dari ruang muat, sehingga para awak kapal harus mengeluarkan air dari dalam ruang muat secara manual dengan menggunakan ember yang diikat dengan menggunakan tali dan kemudian air dibuang keluar dari dalam ruang muat dengan menggunakan ember tersebut sedangkan awak kapal yang lain sedang memperbaiki pompa, sehingga dengan adanya kejadian tersebut proses pembersihan ruang muat membutuhkan waktu yang sangat lama, apabila dalam keadaan normal waktu yang dibutuhkan untuk membersihkan satu ruang muat adalah 5 jam maka dengan adanya kejadian tersebut waktu yang diperlukan untuk membersihkan satu ruang muat menjadi 9 jam.

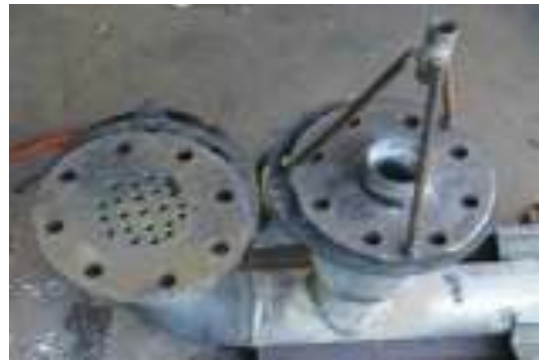

Gambar 4. Pompa got ruang muat

\section{Pembahasan Masalah}

Dalam pembahasan masalah ada beberapa cara untuk membantu memecahkan masalah yang telah dirumuskan dalam penelitian, khususnya pada saat proses pembersihan ruang muat di atas kapal MV. African Forest. Beberapa hal yang akan dibahas adalah sebagai berikut :

\section{Terjadinya keterlambatan dalam proses pemuatan}

Untuk menanggulangi terjadinya keterlambatan proses pemuatan di kapal MV. African Forest maka dapat dilakukan hal-hal sebagai berikut :

\section{a. Mengadakan rapat sebelum pembersihan ruang muat}

Salah satu cara untuk memaksimalkan waktu yang tersedia untuk melakukan proses pembersihan ruang muat adalah dengan cara mengadakan rapat sebelum dan sesudah melakukan proses pembersihan ruang muat.

Tujuan dari mengadakan rapat adalah agar dapat mengevaluasi hasil kerja awak kapal yang tidak sesuai dengan prosedur pembersihan ruang muat sehingga awak kapal dapat lebih mengerti akan tugas dan tanggung jawabnya dalam melaksanakan pembersihan ruang muat di atas kapal. Sehingga proses pembersihan ruang muat dapat berjalan sesuai dengan prosedur dan pembersihan ruang muat dapat selesai tepat waktu dan tidak mengganggu proses pemuatan sehingga proses pemuatan dapat berjalan dengan lancar. 
b. Membuat daftar awak kapal dan bagian ruang muat yang dibersihkan

Salah satu cara untuk mengoptimalkan proses pembersihan ruang muat adalah dengan cara membuat daftar awak kapal dan bagian ruang muat yang dibersihkan dengan cara memberikan sosialisasi kepada awak kapal dengan mengumpulkan awak kapal di crew mess dan menerangkan lewat media slide(power point) proses pembersihan ruang muat yang baik, benar dan sesuai dengan prosedur dan alat-alat yang digunakan dalam proses pembersihan ruang muat serta dilengkapi dengan daftar nama awak kapal dan bagian ruang muat yang harus dibersihkan. Pentingnya pemberian sosialisasi dan pembelajaran mengenai pembersihan ruang muat dan prosedur yang baik, adalah agar awak kapal dalam melaksanakan pembersihan ruang muat dapat sesuai dengan prosedur dan hasil yang didapatkan dapat maksimal.

\section{c. Mengadakan pengawasan}

Dalam proses pembersihan ruang muat, Mualim I selaku perwira yang bertanggung jawab terhadap proses pembersihan ruang muat dibawah Nakhoda harus selalu melakukan pengawasan dan pengecekan terhadap awak kapal yang sedang melakukan proses kebersihan ruang muat jika di perlukan Mualim I dapat turun langsung membantu proses pembersihan ruang muat. Mualim I dapat memberikan bimbingan serta arahan atau instruksi kepada awak kapal yang sedang melakukan proses pembersihan ruang muat, sehingga akan berdampak juga pada psikologis para awak kapal bahwa Mualim I ikut turun dalam proses pembersihan ruang muat dan membakar semangat awak kapal untuk bekerja membersihkan ruang muat sesuai dengan prosedur dan melakukan pembersihan ruang muat dengan maksimal. Sehingga proses pemuatan tidak akan tertunda lagi dikarenakan oleh ruang muat yang masih kotor dan dapat meminimalisir waktu dan biaya yang dilakukan untuk operasional dalam pembersihan ruang muat.

\section{Terjadinya kerusakan alat kebersihan ruang muat}

Untuk menjaga peralatan penunjang kebersihan ruang muat tetap dalam kondisi yang bagus dan siap untuk digunakan dalam proses kebersihan ruang muat di kapal agar persiapan kebersihan ruang muat di kapal MV. African Forest dapat berjalan lancar tidak menemui kendala dan selesai tepat waktu sehingga tidak menghambat proses pemuatan di kapal, dapat melakukan hal-hal sebagai berikut :

\section{a. Menjaga dan merawat peralatan dengan baik}

Salah satu cara untuk mengoptimalkan proses pembersihan ruang muat adalah dengan menggunakan peralatan yang layak pakai untuk mendukung proses kebersihan ruang muat.

Setelah semua awak kapal selesai menggunakan peralatan penunjang kebersihan ruang muat hendaknya dengan penuh kesadaran dan tanggung jawab awak kapal mengembalikan semua peralatan penunjang kebersihan ruang muat pada tempat yang telah disediakan dan ditata dengan rapi sehingga besok apabila akan digunakan kembali untuk membersihkan ruang muat peralatan tersebut dalam kondisi yang siap pakai dan tidak kuarang jumlahnya, setelah peralatan di tata dengan rapi bosun mengecek peralatan tersebut dan melakukan pendataan peralatan yang sudah rusak dan tidak layak pakai lagi untuk diberikan kepada Mualim I dan sebagai Mualim I yang bertanggung 
jawab membuat laporan shipping order Mualim I membuat suatu permintaan atau ship order kepada perusahaan pelayaran atas izin dari Nahkoda dan Kepala Kamar Mesin dalam hal pengadaan peralatan penunjang kebersihan ruang muat yang sudah rusak dan tidak layak pakai serta spare part yang rusak dan sudah tidak bisa diperbaiki lagi.

Pihak perusahaan pun harus mengetahui apa saja yang dibutuhkan oleh setiap armada-armada kapal yang mereka miliki. Ketika melakukan inspeksi di kapal pihak perusahaan harus benar-benar memperhatikan kekurangan-kekurangan pada kapal tersebut, seperti kurangnya alat alat kebersihan ruang muat (sapu, brush, chemical soap, dan anti coorosive).

Dan selanjutnya perusahaan harus melengkapi kekurangan-kekurangan tersebut sesegera mungkin agar semua hal yang berkaitan dengan operasi kapal dapat berjalan dengan lancar. Hal ini harus diimbangi oleh awak kapal penerapannya yang sesuai dengan prosedur agar proses pembersihan ruang muat di atas kapal berjalan maksimal.

\section{b. Meningkatkan kesadaran awak kapal untuk merawat peralatan kebersihan ruang muat}

Salah satu cara untuk mengoptimalkan proses pembersihan ruang muat adalah dengan cara meningkatkan kesadaran awak kapal untuk merawat peralatan kebersihan ruang muat dengan cara mengumpulkan awak kapal dicrew mess pada saat waktu luang atau pada hari libur dan menerangkan lewat media slide (power point) tentang pentingnya merawat alat-alat penunjang kebersihan ruang muat dan proses pembersihan ruang muat yang baik, benar dan sesuai dengan prosedurserta penggunan alat-alat penunjang proses kebersihan ruang muat yang digunakan dalam proses pembersihan ruang muat.

Pentingnya pemberian sosialisasi dan pembelajaran mengenai pembersihan ruang muat dan prosedur yang baik, adalah agar awak kapal dalam melaksanakan pembersihan ruang muat dapat sesuai dengan prosedur dan hasil yang didapatkan dapat maksimal dan awak kapal mempunyai pengetahuan tentang bagaimana cara menggunakan peralatan penunjang kebersihan ruang muat dan pentingnya para awak kapal untuk menjaga dan merawat alat-alat penunjang kebersihan ruang muat.

Mualim I dapat memberikan wawasan kepada awak kapal dan memberi pengarahan bahwa alat-alat penunjang kebersihan di atas kapal harus dijaga dan dirawat dengan baik guna mendukung proses pembersihan ruang muat, serta Mualim I memberi contoh yang baik kepada awak kapal untuk menjaga peralatan penunjang kebersihan ruang muat, sehingga peralatan yang digunakan untuk mendukung proses kebersihan ruang muat tetap terawat dan siap untk digunakan keesokan harinya pada saat melakukan proses pembersihan ruang muat lagi dan proses pemuatan tidak akan terhambat lagi dikarenakan ruang muat yang masih kotor dan belum siap untuk menerima muatan.

\section{KESIMPULAN}

Berdasarkan hasil dari penelitian yang peneliti lakukan terhadap pelaksanaan pembersihan ruang muat pada kapal MV. African Forest dapat disimpulkan sebagai berikut:

1. Waktu yang tersedia dalam mempersiapkan ruang muat belum mencukupi karena awak kapal kurang memaksimalkan waktu yang ada, kurangnya koordinasi antar awak kapal pada saat melakukan proses kegiatan pembersihan ruang muat, kurangnya 
pengawasan dari perwira saat proses kebersihan ruang muat sedang berlangsung, sehingga ruang muat masih kotor karena masih terdapat kotoran dari sisa-sisa muatan sebelumnya dan adanya pemeriksaan oleh surveyor yang memutuskan bahwa ruang muat belum siap, karena masih ditemukan sisa-sisa kotoran dari muatan sebelumnya yang sudah dibongkar dari dalam ruang muat.

2. Perlengkapan kebersihan ruang muat tidak mencukupi karena banyak dari peralatan penunjang kebersihan ruang muat yang sudah rusak dan tidak bisa digunakan secara maksimal untuk melaksanakan proses kebersihan ruang muat yang dikarenakan kesadaran awak kapal yang sangat kurang untuk menjaga dan merawat peralatan penunjang kebersihan ruang muat, dan terlambatnya respons shipping order dari Mualim I kepada kantor perusahaan tentang permintaan alat-alat penunjang kebersihan ruang muat, sehingga ruang muat masih kotor karena masih terdapat kotoran dari sisa-sisa muatan sebelumnya dan adanya pemeriksaan oleh surveyor yang memutuskan bahwa ruang muat belum siap, karena masih ditemukan sisasisa kotoran dari muatan sebelumnya yang sudah dibongkar dari dalam ruang muat.

Berdasarkan kesimpulan dari pelaksanaan proses pembersihan ruang muat pada kapal MV. African Forest, maka peneliti akan memberikan saran-saran agar pelaksanaan pembersihan ruang muat dapat berjalan dengan baik, sehingga tidak terjadi keterlambatan pemuatan pada kapal MV. African Forest, sebagai berikut :

1. Sebaiknya Mualim I membuat jadwal pembersihan ruang muat setelah selesai membongkar muatan dan memaksimalkan kinerja crew kapal dalam persiapan ruang muat, selain itu Mualim I sebaiknya melakukan pengawasan terhadap kinerja awak kapal pada saat melaksanakan kebersihan ruang muat, setelah itu Mualim I sebaiknya melakukan evaluasi kerja setelah proses kebersihan ruang muat selesai dan melakukan pengecekan terhadap ruang muat sebelum cargo surveyor naik ke atas kapal dan melakukan pengecekan terhadap ruang muat.

2. Sebaiknya perusahaan sigap dan tanggap terhadap laporan permintaan yang dikirim oleh pihak kapal dengan mengirimkan peralatan yang berkualitas bagus sehingga peralatan tersebut tidak mudah rusak ketika digunakan untuk proses kebersihan ruang muat, selain itu sebaiknya awak kapal juga mempunyai kesadaran dan tanggung jawab untuk merawat peralatan kebersihan ruang muat, setelah selesai menggunakan alat kebersihan, peralatan tersebut dikembalikan ke ruang penyimpanan (store) dalam keadaan bersih dan ditata rapi sehingga keesokan harinya peralatan tersebut dalam kondisi siap pakai.

\section{DAFTAR PUSTAKA}

Azwar, Saifuddin. 2007. Metode Penelitian. Jakarta : Rineka Cipta

Departemen Pendidikan Nasional. 2014. Kamus Besar Bahasa Indonesia Edisi Baru. Jakarta: Gramedia Pustaka Utama.

Endroyo, Bambang. 2001. Analisis teknik penggunaannya untuk pembelajaran bidang kejuruan teknik bangunan/ sipil. Puspita Rini. Jakarta.

Martopo, Arso dan Soegiyanto. 2001. Penanganan dan pengoperasian muatan

penataan muatan.

Sukardi. 2008. Metodologi Penelitian Pendidikan. Jakarta: Bumi Aksara 
Sugiyono. 2015. Metode Penelitian Kuantitatif, Kualitatif dan $R \& D$. Bandung: CV. Alfabeta

Widoyoko, Putro Eko. 2012. Teknik Penyusunan Instrumen Penelitian. Yogyakarta : Pustaka Pelajar www.generalcargocarier.com, All about General Cargo Carrier diunduh pada tanggal 3 September 2016.

www.kamuskbbi.web.id, Penanganan diunduh tanggal 1 Maret 2017.

Wikipedia. General Cargo. diunduh tanggal 3 Maret 2017. 